\title{
Prediction of Biogas Production in Upflow Anaerobic Sludge Blanket Reactor Based on Fuzzy Rule
}

\author{
Mital J. Dholawala*, Robin A. Christian \\ Department of Civil Engineering, S. V. National Institute of Technology, Surat 395007, Gujarat, India
}

Corresponding Author Email: mital.dholawala@ckpcet.ac.in

https://doi.org/10.18280/ijsdp.150514

Received: 21 March 2020

Accepted: 29 May 2020

\section{Keywords:}

fuzzy model, sensitivity analysis, distillery wastewater, biogas production, UASB reactor, sensitivity index (SI)

\begin{abstract}
The UASB reactor is a popular but complex anaerobic treatment mostly used to treat wastewater loaded with high organic matter. Hence, it is subjected to many complexities due to inconsistent quality and quantity of wastewater and therefore lots of uncertainties are incorporated. Thus, a fuzzy model was developed incorporating five input parameters to predict biogas production in UASBR treating distillery wastewater. A parametric sensitivity analysis of a fuzzy model has been carried out to effectively analyze the influence of input parameters on output. Effect of input parameters on the output parameter has been analyzed through scatter plots. Also, importance based ranking of various input parameters was conducted with the help of the sensitivity index. It was discovered that an increase in biogas production would be achieved if the temperature, COD reduction, COD load and alkalinity to acidity ratio is maintained as $35^{\circ} \mathrm{C}-42^{\circ} \mathrm{C}, 60,000-70,000 \mathrm{mg} / \mathrm{L}, 55,000-65,000 \mathrm{Kg} / \mathrm{Day}$ and $0.1-5$ respectively. Moreover, the sensitivity indices of various parameters revealed that COD load and COD reduction had more importance on predicting biogas production. The results of the present study allow gaining important insights into key parameters which are responsible for affecting the performance of the UASBR under various input conditions.
\end{abstract}

\section{INTRODUCTION}

Anaerobic treatment is a complex kind of biological process in which microorganisms promote stable and self-regulating fermentation and numerous continuous, independent and parallel reactions to convert organic matter into carbon dioxide and methane gases [1]. At present, the anaerobic treatment is becoming more popular amongst environmental engineers and decision-makers as it provides a suitable and sustainable wastewater treatment system in developing countries [2] and also facilitates various advantages over conventional alternatives such as other anaerobic processes like anaerobic lagoons, anaerobic filter reactors etc. and aerobic wastewater treatments [2, 3]. Upflow Anaerobic Sludge Blanket Reactor was first introduced by Lettinga [4] and is now one of the most widely used high rate anaerobic wastewater treatment systems due to its effectiveness to treat varieties of industrial wastewaters including wineries [5], abattoirs [6], distilleries [7] and pharmaceuticals [8] as well as municipal wastewater [9].

UASBR is commonly known for its high metabolic activity and great bioorganic stability [3]. The design and construction of this system is also simple which leads to less initial cost and energy consumption and hence, low operating costs $[2,3,8$, 10-12]. Moreover, it also facilitates biogas production [13], less amount of sludge production [2] and less requirement of land [11] compared to aerobic wastewater treatments. The performance of UASBR fluctuates with many parameters like flow rate, composition, organic loading rate, $\mathrm{pH}$, Hydraulic retention time, Volatile Fatty Acids and temperature [10]. This also causes fluctuation in the biogas production [13] and effluent composition. However, based on the understanding of the process dynamics obtained over the past few decades, several efforts have been done to develop mathematical models for quantifying the performance of a UASB reactor under various operating conditions. Mathematical modeling of wastewater treatment helps taking decisions while designing treatment plants. It can also facilitate the most favorable sizing of wastewater treatment plants, prediction of the composition of the effluent and the impact of the plant on the environment. Miliquez-Sanabria [14] developed the fast linear predictive model of the UASB reactor for onion waste for biofuel production. Dutta [3] evolved the modeling of a pilot-scale UASB reactor to indicate the usability of the Anaerobic Digestion Model (ADM) in the anaerobic process. Different kinetic model equations and mass balance equations have been developed to predict the dynamic response of the anaerobic digester concerning the concentration of methane and total biogas generation rate under different concentrations of carbonaceous substances [15]. Based on the scenario described above, the systems whose explanation would involve a great amount of effort or computational burdens then use of Artificial Intelligence (AI) technology seems to be a very good option because of its ease of use, high-speed operation and accuracy without the need to understand physical issues [16]. Many researchers have used various tools of AI to solve complex problems in a variety of fields [17].

The UASB reactor treating distillery wastewater is a complex process because of several reasons such as variations in pollutant concentrations, influent properties and other physical, chemical, biological factors [18]. Additionally, the stochastic deviations and variability in influent properties 
enforce operators to have proper operational control on the system $[19,20]$. Many uncertainties in the UASB system are caused due to the complexity of anthropogenous activities, treatment process and natural phenomena. Also, the uncertainties arbitrarily keep on fluctuating depending upon the quantity, quality and removal efficiencies of wastewater [18]. Moreover, an increase in strict emission restrictions, regulatory norms for disposal of wastewater into water body, energy efficiency and recycling regulations force to maintain an appropriate efficiency of the wastewater treatment plants [21-23]. Therefore, various AI tools have been used by researchers to conquer these problems. A neural network model has been developed to predict the performance of UASB reactor [24] and also an adaptive neural-fuzzy inference system (ANFIS) has been used to predict the performance of anaerobic digestion treating palm oil effluent [25] but Tu [26] recorded that neural networks are "black box" and require great computational resources as well as they have limited ability to identify the possible practicable relationships. Hence, an attempt has been made to develop a fuzzy rulebased model to predict biogas production in a UASB reactor treating distillery wastewater. A tool like fuzzy logic can frequently be used for understanding complex systems having diverse types of uncertainties [27] Moreover, Fuzzy logic has the capability to converse, reason and make rational decisions in an environment of imprecision, uncertainty, incomplete information, conflicting information, partiality of truth and partiality of possibility [28].

Furthermore, the sizing of the treatment plant is normally done on the basis of various design criteria. However, the change in parametric values of the influent may result in variation of treatment efficiency and therefore, considering the above-described scenario, the parametric sensitivity analysis has also been carried for the developed fuzzy rule-based model to study the robustness of the model.

Parametric sensitivity analysis is the study of how a change in the input variable of a model affects the output of the model [29]. There is always a need to obtain simple models, measurements of errors, validation of the optimal set of variables and understanding the correlation between input and output parameters to study complex conditions and situations present in different systems and hence to attain these objectives, a sensitivity analysis seems to be the most popularly and commonly used approach. The change in the output due to the variations in the input shows how sensitive the system is to these changes. Sensitivity analysis is a powerful tool that verifies how the uncertainties of the parameters are correlated with uncertainties of the output of the system. Tian [30] amalgamated the classic methods of sensitivity analysis, categorizing them into three classes. i) Operating only one variable at a time ii) Generating input matrix and output vector iii) separating specific input vector depending on the output vector. Nevertheless, these methods are meant for the systems which involve high complexity and hence their applications impart more computational burden. Kumar [31] proposed a new method, named as Mehar's method to conduct sensitivity analysis for Fuzzy Linear Programming (FLP) problems. Also, an innovative tabular method has been proposed to deal with the sensitivity analysis of fully FLP problems by Singh [32] involving a detailed study of different SA methods for building energy models considering the small residential building. A novel method of sensitivity analysis has been evolved by Keita [33] to identify and confirm the main parameters which influence the groundwater vulnerability to pollution with fuzzy optimization for the case of the Senegal River basin in Mali. From the literature, it is observed that the local and global sensitivity analysis methods are still applied in evaluating the robustness of a model.

The present paper addresses the One At a Time (OAT) concept to analyze the rate of change in a model output with respect to the values given through a set of model inputs, especially model parameters. The sensitivity analysis has been carried out for the fuzzy rule-based model which incorporates five input variables and one output variable. Local sensitivity analysis (LSA) methods allow examining the sensitivity of output under the variation in the model parameters, with respect to some selected nominal values. The performance of the model has been assessed by observing the change in the output that results from a change in a single input parameter while all other input parameters are kept fixed to their nominal values.

\section{MATERIALS AND METHODS}

\subsection{Biogas production in UASBR}

An Up-flow Anaerobic Sludge Blanket Reactor (UASBR) system is well developed and progressive biological anaerobic wastewater treatment in which wastewater is applied to the UASB reactor from the bottom and it starts flowing in an upward direction through activated sludge blanket which contains granules of sludge. The wastewater gets filtered as it passes through the activated sludge blanket and treated because of anaerobic degradation which allows the production of biogas by breaking down the organic content utilizing the presence of the bacteria in the sludge. The internal mixing is made possible due to the continuous flow of wastewater and the movement of gas bubbles in the upward direction as shown in Figure 1. In addition to this, at the top of the reactor, a gasliquid-solid separator (GLSS) is fixed to successfully separate gas, liquid and granules. The biogas is produced as a valuable source of energy through anaerobic digestion. This anaerobic treatment primarily consists of four different processes in the production of biogas in UASBR: Hydrolysis, acidogenesis, acetogenesis and methanogenesis. Firstly, insoluble organic polymers like proteins, carbohydrates are turned into amino acids, sugars, etc. which are then converted into carbon dioxide, ammonia, hydrogen and organic acids. After that, acetic acids are formed from the organic acids finally followed by the conversion into methane and carbon dioxide [24, 34].

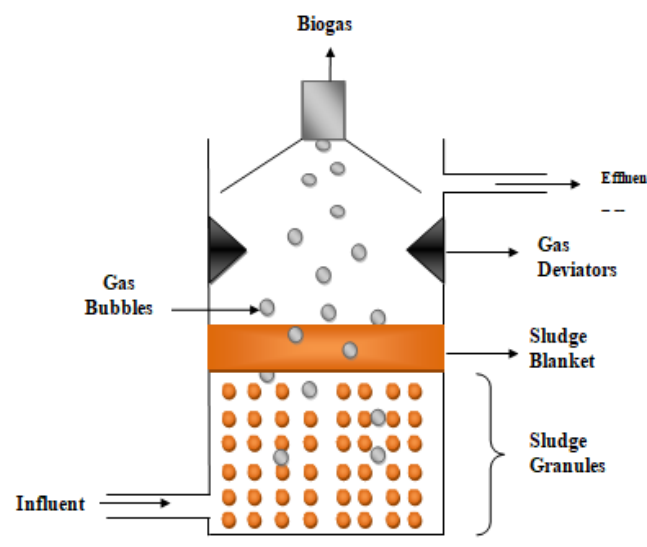

Figure 1. Schematic representation of the UASB reactor 


\subsection{Study area and data collection}

The data has been collected from a wastewater treatment plant of a distillery industry situated at Maharashtra, India. The wastewater treatment plant consists of various units like UASB reactors (4 numbers), buffer tank, biogas holder, storage tank and pumps as shown in Figure 2. The UASB reactor converts organic materials (COD, BOD) into a very small amount of sludge and a large amount of biogas for energy recovery. The UASBR is an anaerobic biological process that reduces $60-70 \% \mathrm{COD}$ and results in the production of biogas having $65-70 \%$ of methane content. The samples of influent and effluent were collected from UASB reactor and different parameters like flow rate, temperature,
$\mathrm{pH}, \mathrm{COD}$, Volatile fatty acids, alkalinity of raw wastewater as well as, temperature, $\mathrm{pH}, \mathrm{COD}$ of treated effluent were measured daily for the duration of one and a half year. The characteristics of wastewater in influent and effluent are presented in Table 1.

Other parameters like COD reduction and alkalinity to acidity ratio obtained from the parameters which are monitored daily to understand the working process of UASBR and also to develop the fuzzy rule-based model. The total COD reduction is a measure of treatment given to the wastewater which is the difference between COD in influent and total COD remaining untreated in the effluent [35]. The ratio of total alkalinity to acidity in the reactor plays a very important role to maintain stability in UASB operation [36].

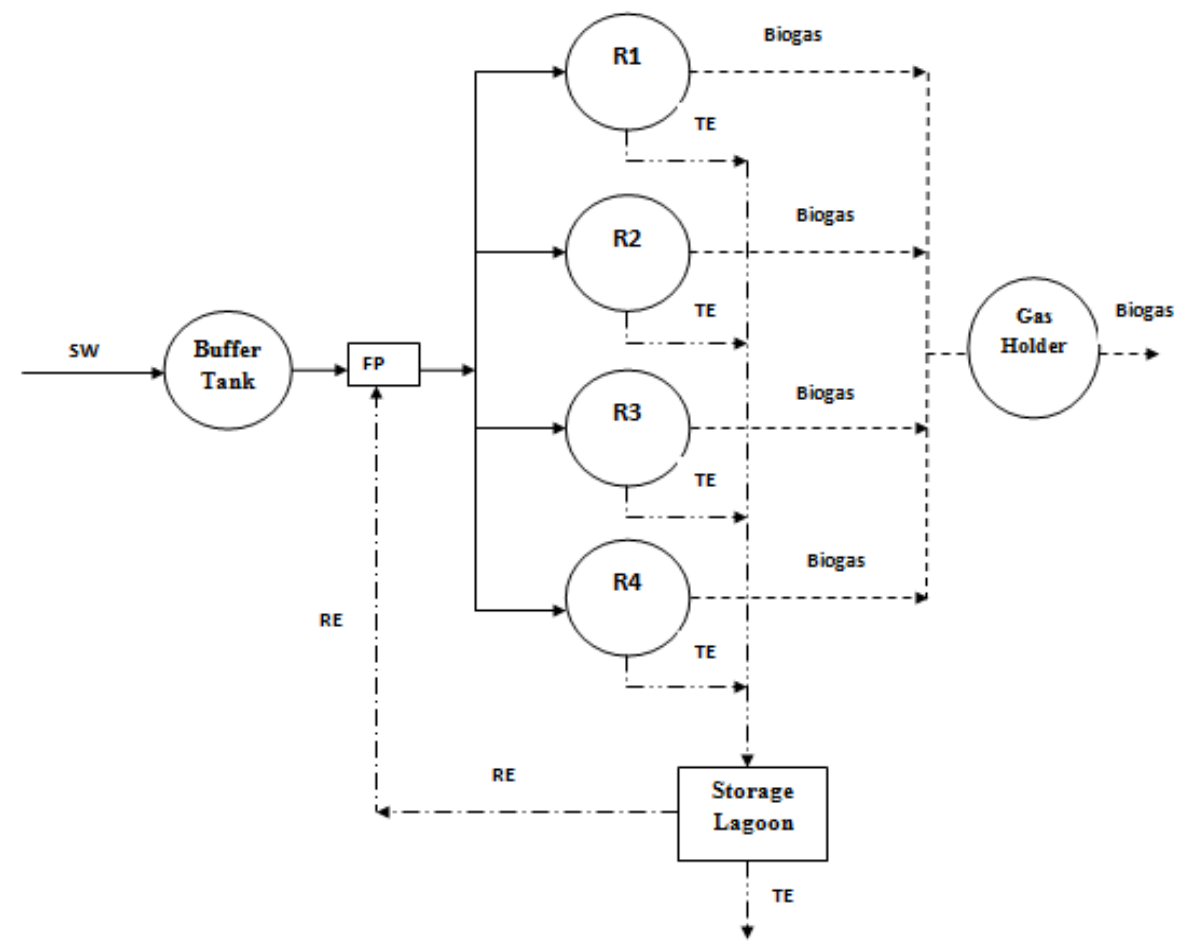

R1, R2, R3, R4 - Reactors, FP- Feeding Pump

SW- Spent Wash, RE- Recycled Effluent, TE - Treated Effluent

Figure 2. Layout of a wastewater treatment plant

Table 1. Summarized wastewater characteristics in Influent $\&$ Effluent of UASBR

\begin{tabular}{cccccc}
\hline Parameter & Unit & Minimum & Maximum & Mean & SD $^{*}$ \\
\hline $\mathrm{pH}$ (in) & - & 3.29 & 4.15 & 3.6 & 0.18 \\
Temp (in) & $\circ \mathrm{C}$ & 27 & 44 & 37 & 3.42 \\
$\mathrm{COD}($ in) & $\mathrm{mg} / \mathrm{L}$ & 58715 & 116069 & 92610 & 9806 \\
$\mathrm{COD}(\mathrm{e})$ & $\mathrm{mg} / \mathrm{L}$ & 16210 & 33850 & 25620 & 2939 \\
$\mathrm{pH}(\mathrm{e})$ & - & 7.13 & 7.73 & 7.41 & 0.14 \\
Temp (e) & $\circ \mathrm{C}$ & 24 & 37 & 31 & 3.24 \\
Flow rate & $\mathrm{m}^{3} /$ Day & 40 & 852 & 541 & 170 \\
Biogas & $\mathrm{m}^{3} /$ Day & 10100 & 44330 & 24260 & 8230 \\
\hline
\end{tabular}

*Standard Deviation

\subsection{Fuzzy rule based model development}

Fuzzy set theory was developed by Lotfi Zadeh in 1965 to deal with the imprecision and uncertainty that is often present in real-world applications [37]. In 1974, Mamdani [38] successfully utilized the IF-THEN rules for the automatic operating control of a steam generator using Zadeh's theories of the linguistic approach and fuzzy inference system [39]. It also provides methods for handling uncertainty and information granularity [40]. Fuzzy modeling presents a powerful tool to understand the behavior of complex nonlinear systems like biological processes [41]. The biogas production rate in UASB reactor treating distillery wastewater is regulated by several factors such as influent characteristics, acclimation of sludge, $\mathrm{pH}$, nutrients, existence of toxic compounds, loading rate, upflow velocity, hydraulic retention time (HRT), liquid mixing, and reactor design that ultimately involve the complexity and uncertainty in the UASB process [1]. Fuzzy Logic System (FLS) consists of mainly four stages: fuzzification, rule base, inference system and defuzzification [42] as shown in Figure 3. Fuzzification involves the conversion of crisp inputs and outputs into fuzzy values employing the degree of membership of the one or more fuzzy sets characterized by linguistic variables such as low, medium, high, very high, etc. $[43,44]$. Thereafter, the fuzzy IF-THEN rules are generated and operated by the fuzzy inference system followed by converting a set of fuzzy inputs into 
corresponding outputs [42]. Most commonly used operators such as "AND" (minimum) and " OR" (maximum) have been applied at this stage. Finally, the fuzzy output established as a result of the fuzzy inference system is then converted into a crisp value during the stage of defuzzification [42, 43]. There are many methods like center of gravity (COG or centroid), bisector of area, mean of maxima, left most maximum, right most maximum, etc. available to conduct defuzzification but the center of gravity (COG or centroid) method has been used in the present study as the same method has been preferred by many researchers [42].

The centroid method [43] may be expressed as given below in Eq. (1):

$$
\left(X_{i}\right)_{d}=\frac{\sum_{i=1}^{n} \mu(x i) x i}{\sum_{i=1}^{n} \mu(x i)}
$$

where, $\left(X_{i}\right)_{d}$ is the crisp output, $x i$ is the output value (or the centroidal distance from the origin) in the $\mathrm{i}^{\text {th }}$ subset, and $\mu(x i)$ is the membership function of the output value in the $\mathrm{i}^{\text {th }}$ subset. A stepwise structure of the fuzzy rule-based model developed in the current study is shown in Figure 4.

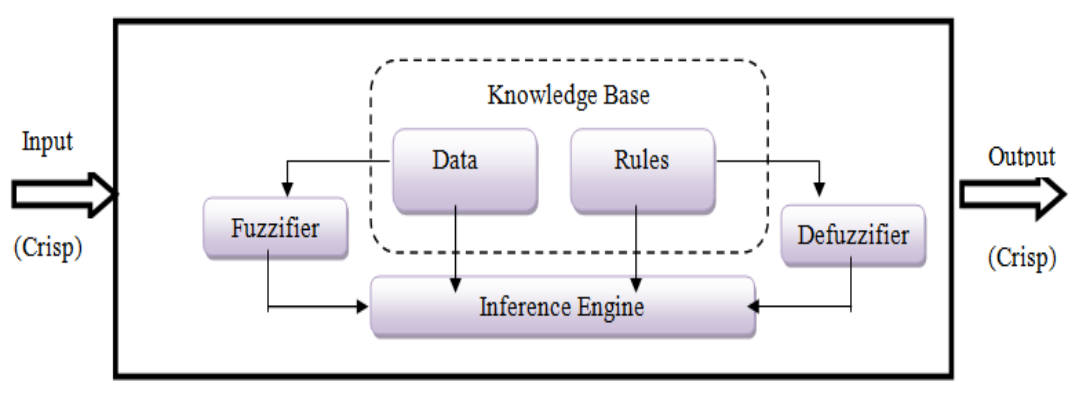

Figure 3. Fundamental segments of a fuzzy rule-based system

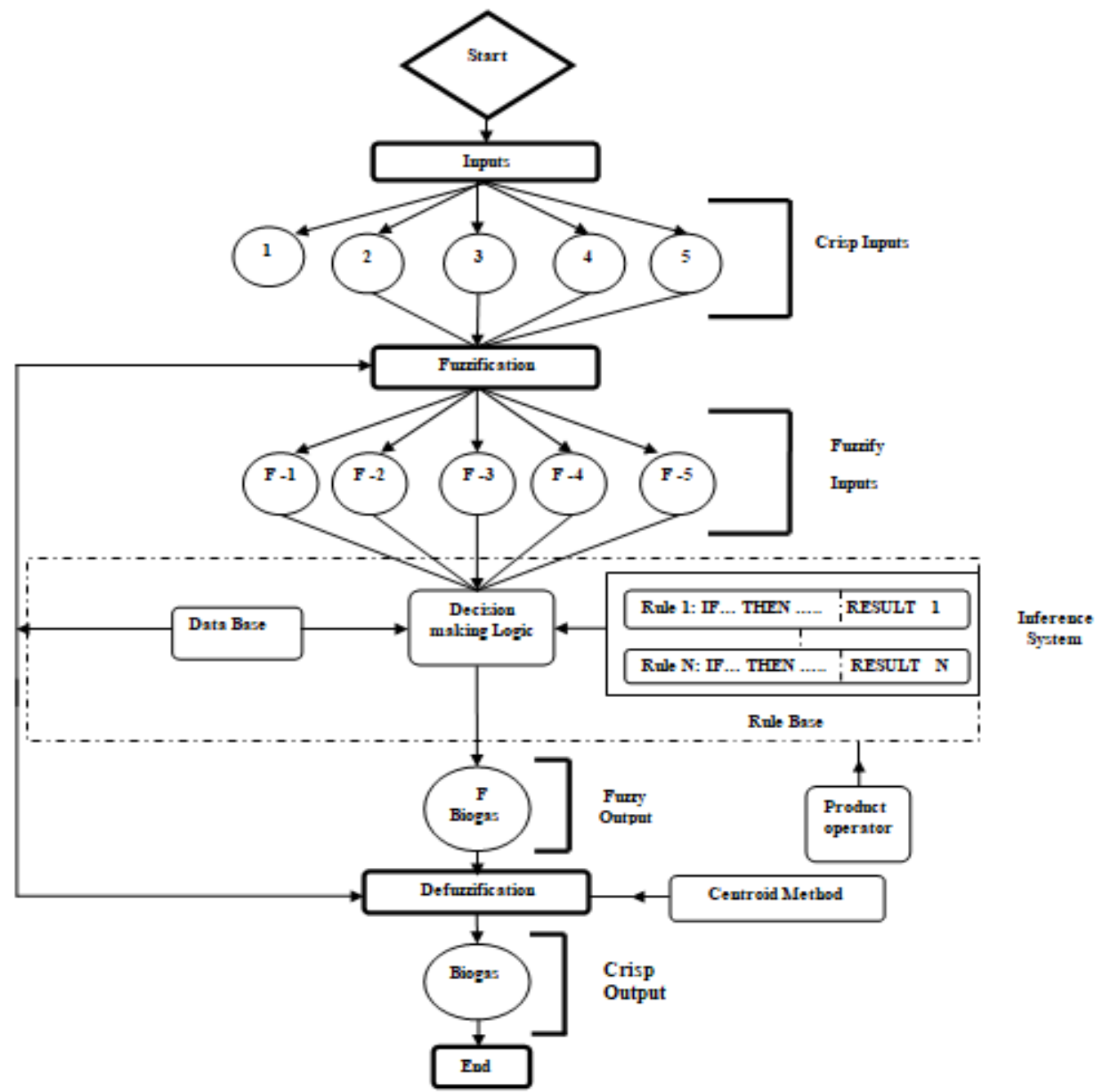

1-Temp., 2-COD Reduction, 3-pH(influent), 4- COD Load, 5- Alkalinity to acidity ratio

Figure 4. Structure of the fuzzy rule-based model used in the present study 
2.3.1 Selection of input variables in the fuzzy rule-based model

Selection of the most suitable input variables which signify the performance of the upflow anaerobic sludge blanket reactor (UASBR) could make it easy to identify possible technical faults and to minimize the operational and maintenance costs at the stage of planning. Several combinations have been found in the literature for the selection of an appropriate set of input variables for the fuzzy model [45-47]. Although the model inputs are chosen based on the data which have been monitored daily from a real scale plant. Therefore, temperature, COD reduction, $\mathrm{pH}$ (influent), COD load and alkalinity to acidity ratio have been selected as input parameters to develop a fuzzy rule-based model for the prediction of biogas production in UASB reactor treating distillery wastewater.

\subsubsection{Fuzzification}

In fuzzy logic, the membership functions (MFs) are defined to express the possibilities of uncertainties present in the real situation. The belongingness of each element in the set varies from 0 to $1[42,43]$. Several types of membership functions such as triangular, trapezoidal, bell-shaped, sigmoidal etc. [42, 43] can be adopted depending upon the type of the problem being studied. However, triangular and trapezoidal membership functions are employed in this study due to their quality of being easy to understand and implement for the fuzzy information [42]. The ordinates of triangular and trapezoidal membership functions are adjusted until the satisfactory results of the output are achieved for defined fuzzy rules $[42,43]$

A triangular MF [43] is expressed using three parameters $\{a$, b, c \} as given below in Eq. (2):

$$
\operatorname{triangle}(x ; a, b . c)=\left\{\begin{array}{l}
0, x \leq a \\
\frac{x-a}{b-a}, a \leq x \leq b \\
\frac{c-x}{c-b}, b \leq x \leq c \\
0, c \leq x
\end{array},\right.
$$

A trapezoidal MF [43] is defined by four parameters $\{a, b$, c, d\} as shown in Eq. (3):

$$
\operatorname{trapezoid}(x ; a, b . c, d)=\left\{\begin{array}{l}
0, x \leq a \\
\frac{x-a}{b-a}, a \leq x \leq b \\
1, b \leq x \leq c \\
\frac{d-x}{d-c}, c \leq x \leq d \\
0, d \leq x
\end{array},\right.
$$

The fuzzy rule-based model has been developed using the Fuzzy Logic Toolbox in MATLAB. Several fuzzy sets are assigned to characterize the various levels of numerical data for five input variables and the output variable using Eq. (2) \& (3). Fuzzy sets are defined by selecting different linguistic variables such as Low (VL), Medium Low (ML), Low (L), Medium (M), Medium High (MH), High (H), Very High (VH), Extremely High (EH). Based on the range of the data for each input and output variable, different number of membership functions have been chosen. In addition to that, minimum and maximum values for each input and output have been considered to increase the performance and flexibility of the model to predict biogas production in UASBR. The membership functions for different variables temperature, COD Reduction, $\mathrm{pH}$ (influent), COD Load, alkalinity to acidity ratio and biogas production are shown in Figures 5, 6, 7, 8, 9 and 10 respectively.

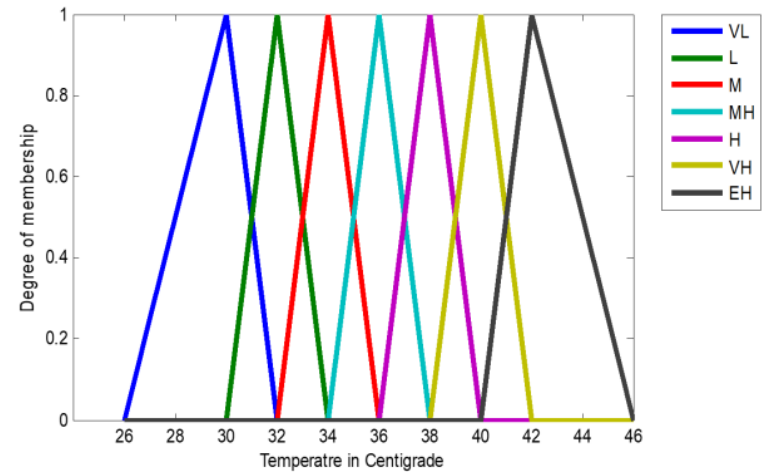

Figure 5. Membership functions for Temperature $\left({ }^{\circ} \mathrm{C}\right)$

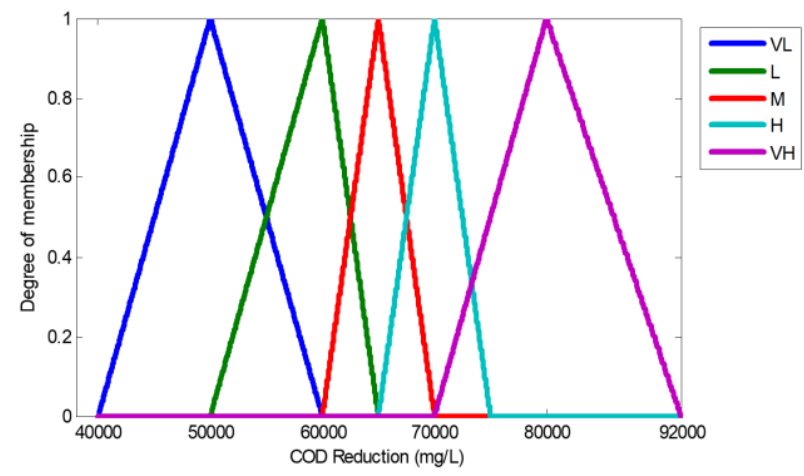

Figure 6. Membership functions for COD Reduction

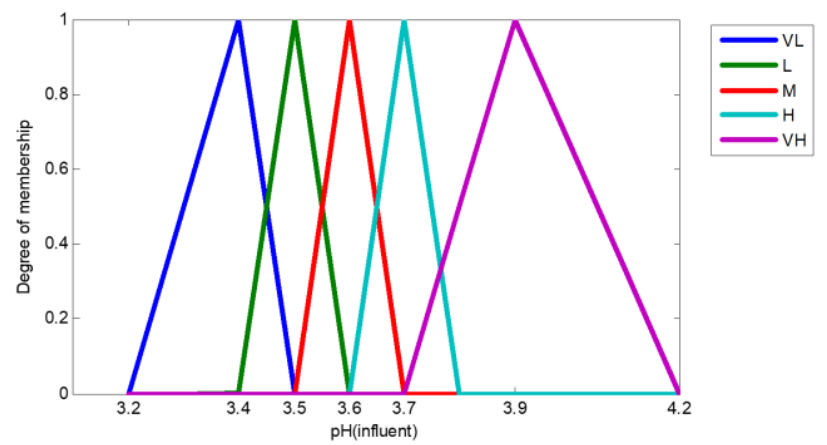

Figure 7. Membership functions for $\mathrm{pH}$ (influent)

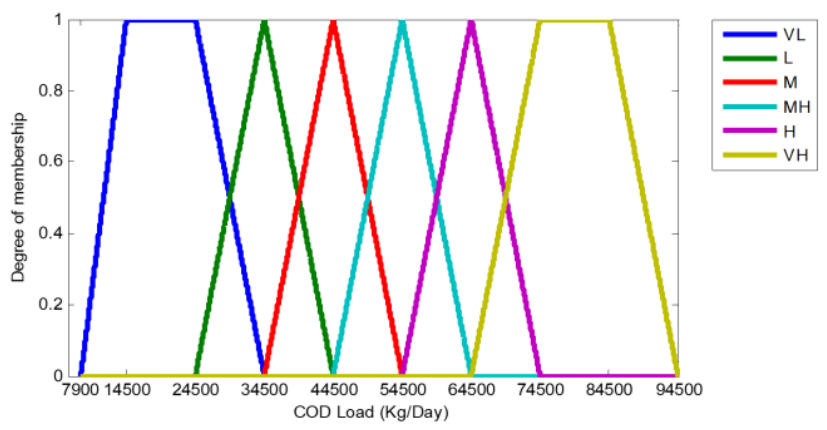

Figure 8. Membership functions for COD Load 


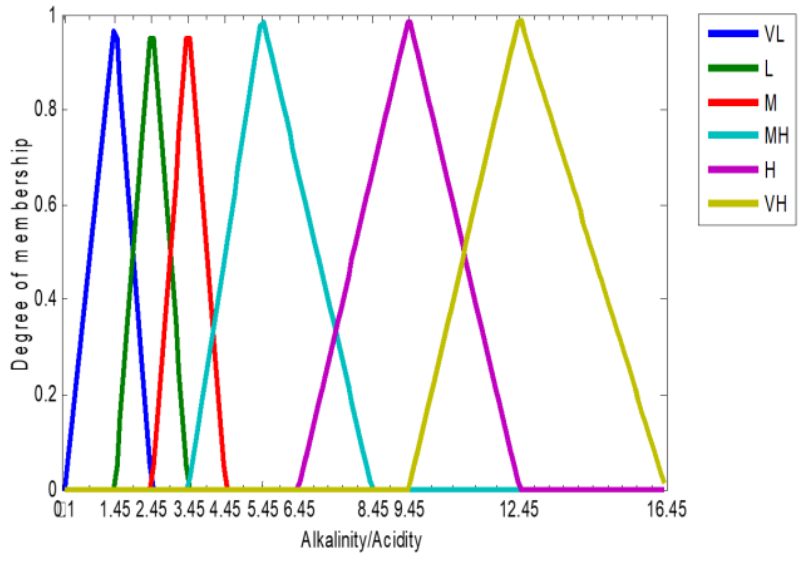

Figure 9. Membership functions for alkalinity to acidity ratio

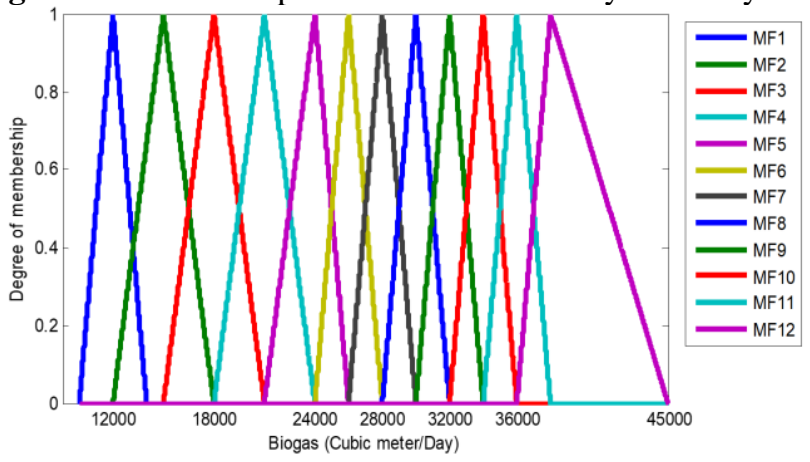

Figure 10. Membership functions for Biogas ( $\mathrm{m}^{3} /$ Day)

\subsubsection{Fuzzy inference engine}

The fuzzy IF-THEN rules have been generated in the FIS rule editor considering all possible combinations of membership functions of inputs (antecedent- IF) and output (consequent- THEN) with the help of experience and the numerical data in the present study. Two fuzzy inference systems namely Mamdani FIS [42] and Takagi-Sugeno FIS [42] can be used for a variety of control and prediction applications. However, Mamdani FIS is the most commonly adopted system by many researchers [48-50] for a range of applications than the Takagi-Sugeno FIS because of its ease of composition and interpretation [51]. Hence, Mamdani FIS has been employed in the present study.

\subsubsection{Defuzzification}

At this stage, the fuzzy results of the fuzzy inference system are defuzzified and converted into real values using the centroid as described in section 2.3.

\subsection{Validation of the model}

The validation of the fuzzy rule-based model has been carried out by testing data that were not utilized at the time of development of the model. Additionally, evaluation of the fuzzy rule-based model has been conducted by determining a root mean square error (RMSE) as a performance measure [5255] using Eq. (4).

$$
R M S E=\sqrt{\frac{\sum_{i=1}^{n}\left(X_{O i}-X_{M i}\right)^{2}}{n}}
$$

where, $X_{o}$ are observed values and $X_{M}$ are predicted values and $\mathrm{n}$ is a number of samples.

\subsection{A simplified method to evaluate fuzzy rule based model}

Sensitivity Analysis (SA) is a tool used to map the relationship between model output and its input parameters and also to evaluate the robustness of the model. Also, it facilitates to recognize and rank the input variables with the maximum impact on the output [56].

\subsubsection{Sensitivity Analysis (SA)}

One-at-a-time (OAT) or one-factor-at-a-time (OFAT) is the most commonly used method to conduct local SA. In this method, sensitivity indices are determined when only one input parameter is varied and all other variables are kept fixed [56]. This seems a logical approach as any change occurred in the output will be due to the variation in the input. This method has numerous advantages over global SA methods. This method is very easy to apply and interpret in comparison with global methods. Also, it is less time consuming as it requires fewer simulation runs compared to global sensitivity analysis. The calculation of the sensitivity index $[56,57]$ for every input parameter can be done by assessing the partial derivatives of output (y) with each input parameter (xi) as expressed in Eq. (5)

$$
S_{i}^{O A T}=\frac{\partial y}{\partial x_{i}} \quad i=1,2,3 \ldots n
$$

where, $S_{i}$ is the input variable index, $y$ is a single output, and $x_{i}$ is the $i^{\text {th }}$ input variable. However, in most cases, it is very difficult to find analytical solutions of these partial derivatives particularly when the output is determined by complex or nonlinear formulas. Hence, sensitivity indices can be obtained using Eq. (6) in a numerical form with the help of finite difference in this type of cases [57].

$$
S_{i}^{O A T}=\frac{y^{\prime}-y_{0}}{x_{i}^{\prime}-x_{i 0}} \quad i=1,2,3 \ldots n
$$

where, $y^{\prime}$ is the output determined at the perturbed input $x_{i}{ }^{\prime}$ and $y_{0}$ and $x_{i 0}$ are the nominal values (base values) for the output and the $i^{\text {th }}$ input variable, respectively. The sensitivity index is normalized using Eq. (7) to establish its dimensionless form as follows [57]:

$$
S_{i, \text { norm }}^{\text {OAT }}=\frac{\left(\frac{y^{\prime}-y_{0}}{y_{0}}\right)}{\left(\frac{x^{\prime}-x_{i 0}}{x_{i o}}\right)} i=1,2,3 \ldots n
$$

It is a general method to use $S_{i, \text { norm }}^{O A T}$ for obtaining importance based ranking of the parameters to separate their unit from affecting the ranking [57].

2.5.2 Steps involved in a parametric sensitivity analysis of a fuzzy rule-based model

One At a Time (OAT) methodology has been used to conduct the parametric sensitivity analysis in fuzzy modeling incorporating five input parameters temperature, COD reduction, $\mathrm{pH}$ (influent), COD load and alkalinity to acidity ratio and one output parameter biogas production. 
(1). The frequency distribution diagrams have been developed to determine the nominal values (base values) of input parameters temperature, COD reduction, $\mathrm{pH}$ (influent), COD load and alkalinity to acidity ratio as shown in Figures $12,14,16,18$ and 20 respectively. The real data observations have been classified into different sets and further, the nominal value $[57,58]$ of each input parameter has been decided considering the most frequently occurred set of observations.

(2). The prediction of biogas production in the fuzzy rulebased model has been monitored while the value of one input parameter changed to any value between the minimum and maximum data of that specific input parameter keeping all other inputs fixed to their nominal values.

(3). The results of sensitivity analysis can be represented in different ways like scatter plot, Tornado plot, box plot, spider plot etc. However, scatter plots are a good preparative way to understand the relationship between inputs and outputs [58]. Hence, all input parameters and their effects on biogas production have been comprehensively analyzed using scatter plots.

(4). The normalized sensitivity index of various input parameters was determined using Eq. (7) to study the relative importance of the parameters to predict biogas production in a fuzzy rule-based model.

\section{RESULTS AND DISCUSSIONS}

\subsection{Prediction of biogas production rate}

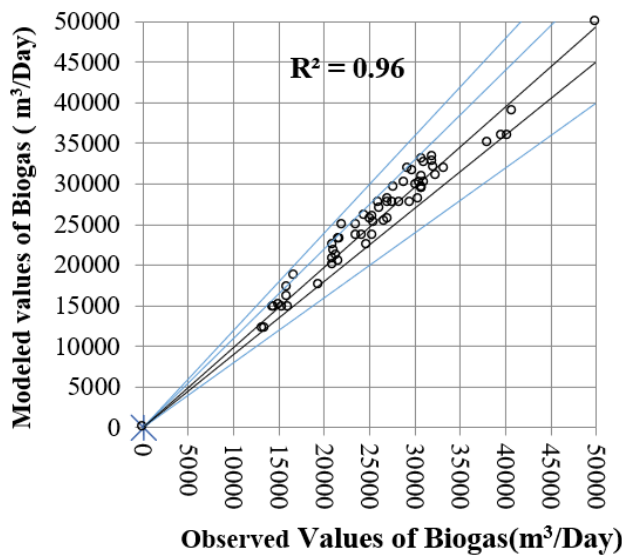

Figure 11. Scatter plot between observed and modeled values of biogas production ( $\mathrm{m}^{3} /$ Day)

In the present work, the developed fuzzy rule-based model incorporating five input variables such as temperature, COD Reduction, COD Load, pH(influent) and Alkalinity to acidity ratio has been used to predict biogas production rate in upflow anaerobic sludge blanket reactor (UASBR) treating distillery wastewater. Thereafter, the performance of the fuzzy rulebased model with five inputs has been evaluated by plotting scatter plot between modeled and observed values of biogas production as shown in Figure 11 which clearly indicates the finer predictive ability of the fuzzy model as nearly all the points are found to be very closer to the best fit line. Moreover, coefficient of determination $\left(\mathrm{R}^{2}\right)$ [43, 59] and root mean square error (RMSE) [52-55] were determined to be 0.96 and $1596 \mathrm{~m}^{3} /$ Day respectively which also shows a significantly stronger performance of the fuzzy rule-based model. In addition to this, Ndobeni et al. 2019 [60] developed quadratic models with $\mathrm{R}^{2}$ value 0.65 which also justified the better performance of the fuzzy model for the prediction of biogas in UASB reactor. The $\mathrm{R}^{2}$ value of optimum ANFIS models for methane yield was found to be 0.9 which proved the remarkable performance of the fuzzy model [61]

\subsection{Evaluation of fuzzy rule based model}

The parametric sensitivity analysis in fuzzy modeling has been carried out using OAT methodology to assess the robustness of the fuzzy rule-based model and to evaluate the influence of the input parameters on biogas production in the UASB reactor. Also, the normalized sensitivity indices (Eq. (7)) of input parameters temperature, COD Reduction, $\mathrm{pH}$ (influent), COD Load and alkalinity to acidity ratio are found to be $0.56,2.25,0.36,1.92$ and 0.71 respectively as shown in Table 2. A higher value of sensitivity index indicates the high impact of that input parameter on biogas production [56]. Hence, based on the values given in Table 2, it has been noted that COD reduction and COD load are relatively more sensitive than other parameters.

Table 2. Sensitivity indices for different fuzzy input parameters

\begin{tabular}{ccc}
\hline Sr. No. & Input parameter & Sensitivity Index (SI) \\
\hline 1 & Temperature & 0.56 \\
2 & COD Reduction (mg/L) & 2.25 \\
3 & pH(influent) & 0.36 \\
4 & COD Load & 1.92 \\
5 & Alkalinity to Acidity Ratio & 0.71 \\
\hline
\end{tabular}

\subsubsection{Effect of varying temperature}

The temperature varies from $26^{\circ} \mathrm{C}$ to $46^{\circ} \mathrm{C}$ as shown in Figure 12. The result of sensitivity analysis for temperature is represented by plotting scatter diagram as shown in Figure 13. It has been observed from Figure 13 that the biogas production increases with the increase in temperature between the range of $35^{\circ} \mathrm{C}$ to $42^{\circ} \mathrm{C}$. Furthermore, it has been noticed from the frequency distribution diagram (Figure 12) that the maximum temperature data also fall in the same range of $38.5^{\circ} \mathrm{C}$ to $42.4^{\circ} \mathrm{C}$. Hence, from these observations, it is concluded that the maximum biogas is produced if the temperature is maintained between $35^{\circ} \mathrm{C}$ to $42^{\circ} \mathrm{C}$ which indicates the stabilized performance of the UASB reactor. In addition to this, the result of the coefficient of determination $\left(\mathrm{R}^{2}\right)$ has been found to be 0.87 which specifies remarkable nonlinear correlation between temperature and biogas production. The value of sensitivity index $(\mathrm{SI}=0.56)$ revealed that temperature is a more sensitive input parameter in fuzzy modeling to predict biogas production in UASB reactor in comparison to $\mathrm{pH}$ (influent) ( $\mathrm{SI}=0.36)$ and less sensitive than alkalinity to acidity Ratio (SI=0.71), COD Load (SI=1.92), COD Reduction ( $\mathrm{SI}=2.25$ ).

Moreover, from the literature, it has been said that the growth, metabolism, and survival of microorganisms in the UASB reactor are greatly affected by the change in the temperature. The efficiency of anaerobic digestion can accomplish the best outcomes within the optimal range of temperatures. The anaerobic process can be carried out at three possible ranges of temperatures i.e. psychrophilic $15-25^{\circ} \mathrm{C}$, mesophilic $35-45^{\circ} \mathrm{C}$ and thermophilic $50-60^{\circ} \mathrm{C}$ [62]. The nucleic acids, proteins, and other cellular components will get affected badly if the temperature is kept higher than the optimal range and also the UASB system will get collapse 
since microorganisms fail to get suitable conditions [63] Hence, Nowadays most of the UASB systems are mesophilic $\left(35^{\circ} \mathrm{C}-45^{\circ} \mathrm{C}\right)$ because the thermophilic $\left(>50^{\circ} \mathrm{C}\right)$ use too much energy while psychrophilic $\left(15-25^{\circ} \mathrm{C}\right)$ meet up many obstacles [34].

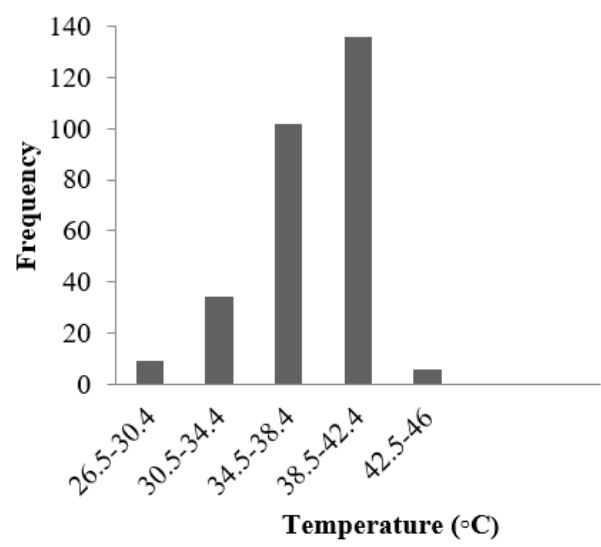

Figure 12. Frequency distribution for temperature $\left({ }^{\circ} \mathrm{C}\right)$

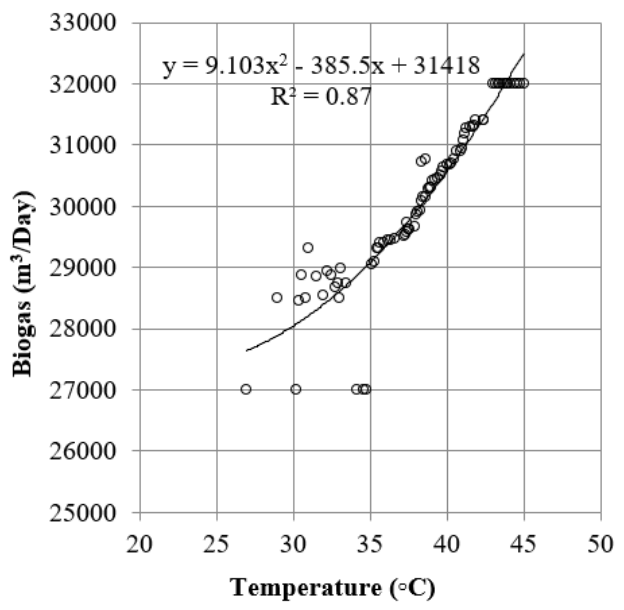

Figure 13. Sensitivity analysis of temperature $\left({ }^{\circ} \mathrm{C}\right)$

\subsubsection{Effect of varying COD reduction}

From Figure 15, it is perceived that the slope of the best fit line and $\mathrm{R}^{2}$ as 0.91 indicate a stable and strong correlation between COD reduction and biogas production. Also, it is seen that biogas production increases extensively when the COD reduction has been achieved between 60000-70000 mg/L which is also the most frequently occurred range of the data (Figure 14). Therefore, it can be said that high biogas production would be obtained if the COD reduction in the UASBR is achieved within $60000-70000 \mathrm{mg} / \mathrm{L}$. Also, the sensitivity index as 2.25 revealed that COD reduction is a highly sensitive input parameter to predict biogas production in a fuzzy model compared to other input parameters.

Additionally, literature also stated that the COD reduction is the difference between substrate concentrations of influent and effluent. It is a measure of substrate utilization efficiency and microbial metabolic activity which plays a very important role in any biological process. It can also be very well understood from the literature that high COD removal has been obtained in the treatment of wastewaters containing very high organic matter such as distillery wastewater [64], textile wastewater [65], dairy wastewater [66] etc. with the use of anaerobic biological processes.

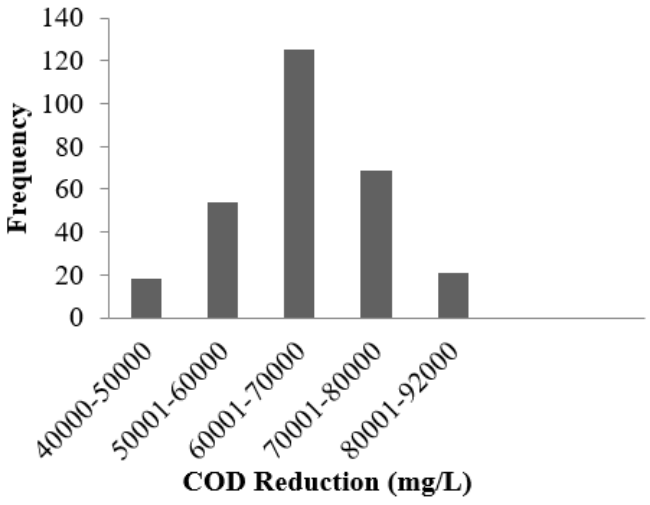

Figure 14. Frequency distribution for COD Reduction

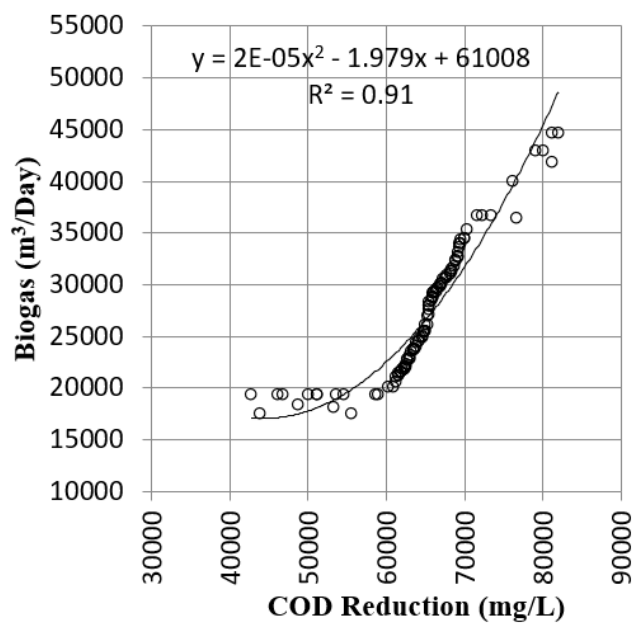

Figure 15. Sensitivity analysis of COD reduction $(\mathrm{mg} / \mathrm{L})$

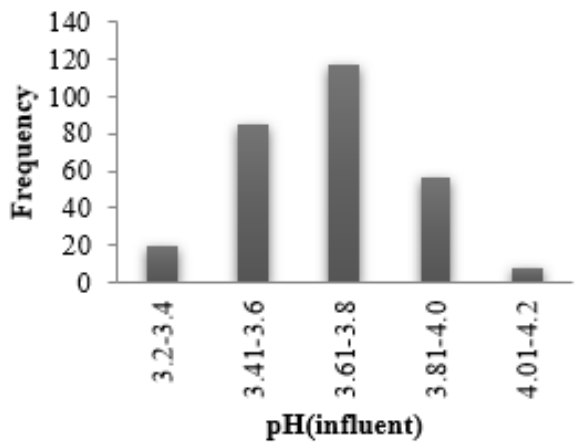

Figure 16. Frequency distribution for $\mathrm{pH}$ (influent)

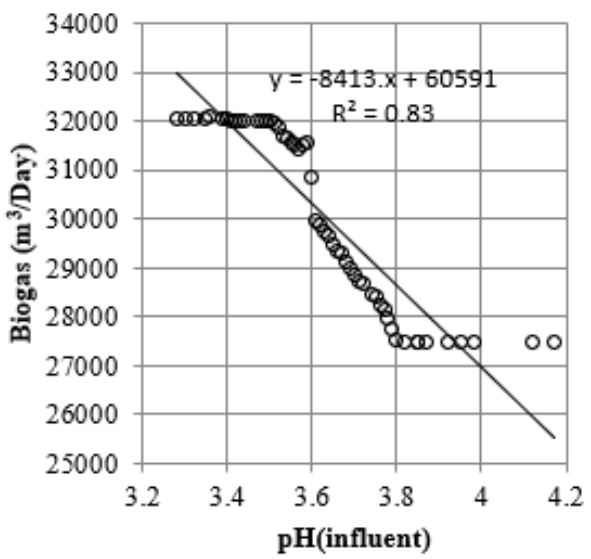

Figure 17. Sensitivity analysis of pH(influent) 


\subsubsection{Effect of varying pH(influent)}

The Sensitivity Index (SI) of $\mathrm{pH}$ (influent) has found to be 0.36 (Table 2) which represents the lowest sensitive input parameter of the fuzzy model in comparison with other parameters. Moreover, the coefficient of determination $\mathrm{R}^{2}$ of 0.83 shows the moderately important negative correlation between $\mathrm{pH}$ (influent) and biogas production (Figure 17). The sensitivity of $\mathrm{pH}$ (influent) on Biogas production rate is represented in Figure 17. It has been observed that biogas production decreases with the increase in $\mathrm{pH}$ (influent) between the range of 3.5 to 3.8 which is also the most frequently occurred range of the data (Figure 16). The possible reasons for the reduction in biogas production when the $\mathrm{pH}$ ranges from 3.4 to 3.8 are discussed here. The data of $\mathrm{pH}$ (influent) varies between 3.2 to 4.2 (Figure 16) which seems highly acidic. It is very clear from the literature that the most favorable $\mathrm{pH}$ for the anaerobic treatment ranges between 5.5-6.5 [67]. Methane producing bacteria are highly sensitive to $\mathrm{pH}$ value and the suitable range of $\mathrm{pH}$ for these bacteria is 6.5-7.8 while acid-producing bacteria work efficiently between the $\mathrm{pH}$ range of 5 to 6 [43]. Moreover, alkalinity plays a very important role in regulating $\mathrm{pH}$ in the reactor and also acts as a pool for $\mathrm{CO}_{2}$ in biogas production [67].

\subsubsection{Effect of varying $\mathrm{pH}$ (influent)}

It is seen from Figure 19 that the biogas production increases greatly when the COD load varies between 55000 $65000 \mathrm{Kg} / \mathrm{Day}$ which is also the most frequently occurred range of the data (Figure 18) and biogas production moderately increases when COD load ranges from 8000$54000 \mathrm{Kg} /$ Day and for more than $65000 \mathrm{Kg} / \mathrm{Day}$. Therefore, it can be said that high biogas production would be achieved if the COD load in the UASBR is varied between 55000-65000 $\mathrm{Kg} / \mathrm{Day}$. Also, the Sensitivity Index value of 1.92 revealed that COD load has a strong impact on biogas production in a fuzzy rule-based model.

Furthermore, the COD loading is the function of the influent flow rate and organic load. The literature also indicated that the COD loading directly affects microbial bionomics and properties of anaerobic systems [68]. It also deals with the operational features of the reactor, growth of microorganisms and microbial activities take place in the reactor [69]. Moreover, it also reflects the capacity of the anaerobic treatment system to convert organic matter into energy resources [69] and hence, literature also proved the importance of COD loading in evaluating the efficiency of anaerobic treatment systems.

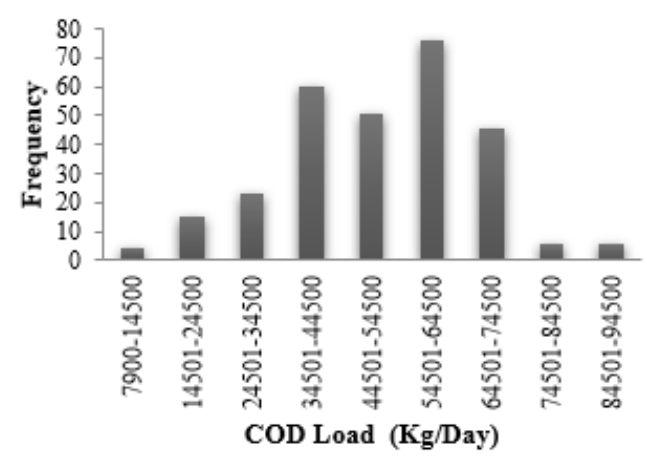

Figure 18. Frequency distribution for COD load (Kg/Day)

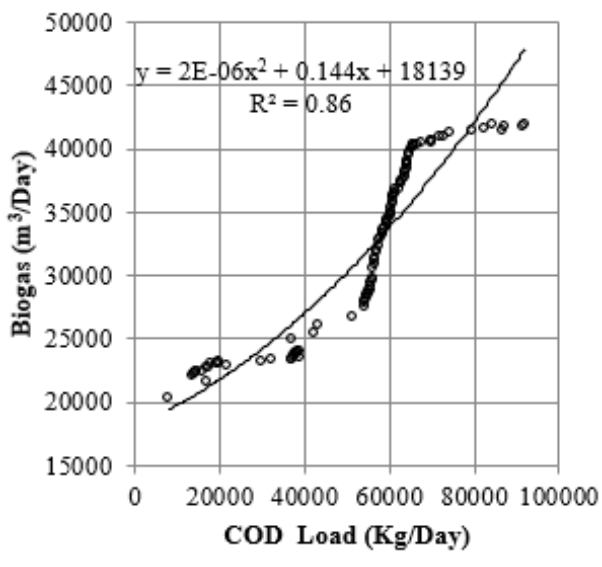

Figure 19. Sensitivity analysis of COD load

Additionally, the organic loading rate (OLR) is an important parameter significantly affecting microbial ecology and the characteristics of anaerobic systems. This parameter integrates the operational characteristics of the reactor and bacterial mass and activity into the volume of media [70]. Verma [71] has reported that OLR is a measure of the biological conversion capacity of the anaerobic treatment system. It depends on the technology used and on the type of wastewater to be treated.

\subsubsection{Effect of varying alkalinity to acidity ratio}

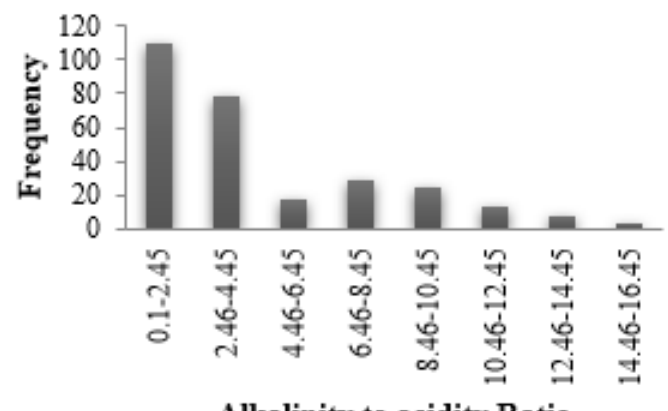

Alkalinity to acidity Ratio

Figure 20. Frequency distribution for alkalinity to acidity ratio

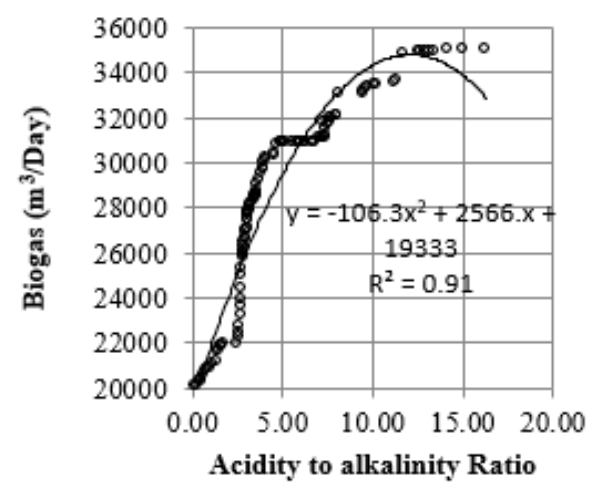

Figure 21. Sensitivity analysis of Alkalinity to acidity Ratio

Figure 21 shows the sensitivity analysis of the input parameter alkalinity to acidity ratio on the output biogas production rate. The slope of the best fit line and $\mathrm{R}^{2}$ value (0.91) represents a significantly strong relationship between the alkalinity to acidity ratio and biogas production as shown in Figure 21. Also, it has been observed that biogas production goes on increasing tremendously when the alkalinity to acidity 
ratio lies between 0.1 to 5 . The maximum data also fall in the same range which can also be noticed from the frequency distribution shown in Figure 20. Further, there is a moderate amount of increase in biogas production when the alkalinity to acidity ratio has been maintained beyond 7 (Figure 21).

Furthermore, the theoretical aspects also signified that alkalinity is a very significant parameter because, in order to neutralize the acids present in the solution, carbonates will supply hydroxide ions which is known as the buffering capacity of alkalinity [72]. This buffering capacity is more helpful in assessing the imbalance in the reactor than direct $\mathrm{pH}$ measurements because the buffering capacity gets reduced remarkably with an accumulation of fatty acids before the $\mathrm{pH}$ decreases [43]. Moreover, alkalinity also plays a very important role in providing a pool for $\mathrm{CO}_{2}$ in biogas production.

\section{CONCLUSIONS}

In the present study, an artificial intelligence-based fuzzy model was developed incorporating five input parameters temperature, COD Reduction, pH(influent), COD Load and alkalinity to acidity ratio to predict biogas production in upflow anaerobic sludge blanket reactor treating distillery wastewater. The coefficient of determination $\mathrm{R}^{2}(0.96)$ and root mean square error $\left(1526 \mathrm{~m}^{3} /\right.$ day) indicated efficient and precise predictions of biogas production with the proposed fuzzy rule-based model. Further, the complex reactions and their mathematical or biochemical equations involved in a complex system like anaerobic treatment are not needed to be established to develop the fuzzy logic model which makes it very simple and easy to apply in various fields.

Additionally, an attempt has been made to carry out the parametric sensitivity analysis of the fuzzy rule-based model parameters to study the robustness of the model and the relationship between input and output parameters using OAT methodology. The results of coefficients of determination $\mathrm{R}^{2}$ and sensitivity indices showed that COD reduction and COD load had more importance and sensitivity than other input parameters in predicting biogas production. The OAT method has been found to be a simple and reliable method to observe the impact on the output variable with respect to the small variation in the inputs. Also, it is discovered that this type of sensitivity analysis will help the process control engineer to assess biogas production rates in UASBR which are needed to control the working and operation of the anaerobic process. The results of the parametric sensitivity analysis allow gaining important insights into key parameters which are responsible for affecting the performance of the UASB reactor under various input conditions. Furthermore, parametric sensitivity analysis helps decision analysts to understand the uncertainties, pros and cons with the limitations and scope of a decision model. It provides an appropriate insight into the problems associated with the model. Finally, the decision-maker can have a decent idea about how sensitive is the optimum solution to any changes in the input values of one or more parameters.

However, the OAT concept does not consider the interactions between the input variables so other techniques like global sensitivity analysis methods can also be used to get the idea about the interactions between input variables although the global methods are computationally intensive and time-consuming.

\section{REFERENCES}

[1] Daud, M.K., Rizvi, H., Akram, M.F., Ali, S., Rizwan, M., Nafees, M., Jin, Z.S. (2018). Review of upflow anaerobic sludge blanket reactor technology: Effect of different parameters and developments for domestic wastewater treatment. Journal of Chemistry, 2018: 1596319. http://dx.doi.org/10.1155/2018/1596319

[2] Khan, A.A., Gaur, R.Z., Tyagi, V.K., Khursheed, A., Lew, B., Mehrotra, I., Kazmi, A.A. (2011). Sustainable options of post-treatment of UASB effluent treating sewage: A review, Resource Conservation Recycle, 55(12):

1232-1251.

https://doi.org/10.1016/j.resconrec.2011.05.017

[3] Dutta, A., Davies, C., Ikumi, D.S. (2018). Performance of upflow anaerobic sludge blanket (UASB) reactor and other anaerobic reactor configurations for wastewater treatment: a comparative review and critical updates. Journal of Water Supply: Research and TechnologyAqua, 67(8): 858-884. https://doi.org/10.2166/aqua.2018.090

[4] Lettinga, G.A.F.M., Van Velsen, A.F.M., Hobma, S.D., De Zeeuw, W., Klapwijk, A. (1980). Use of the upflow sludge blanket (USB) reactor concept for biological wastewater treatment, especially for anaerobic treatment. Biotechnology and Bioengineering, 22(4): 699-734. https://doi.org/10.1002/bit.260220402

[5] Parawira, W., Kudita, I., Nyandoroh, M.G., Zvauya, R. (2005). A study of industrial anaerobic treatment of opaque beer brewery wastewater in a tropical climate using a full-scale UASB reactor seeded with activated sludge. Process Biochemistry, 40(2): 593-599. https://doi.org/10.1016/j.procbio.2004.01.036

[6] Miranda, L.A.S., Henriques, J.A.P., Monteggia, L.O. (2005). A full-scale UASB reactor for treatment of pig and cattle slaughterhouse wastewater with a high oil and grease content. Brazilian Journal of Chemical Engineering, 22(4): 601-610. https://doi.org/10.1590/S0104-66322005000400013

[7] Ince, O., Kolukirik, M., Oz, N.A., Ince, B.K. (2005). Comparative evaluation of full-scale UASB reactors treating alcohol distillery wastewaters in terms of performance and methanogenic activity. Journal of Chemical Technology \& Biotechnology: International Research in Process, Environmental \& Clean Technology, $\quad$ 80(2): 138-144. https://doi.org/10.1002/jctb.1154

[8] Chen, Z., Wang, H., Chen, Z., Ren, N., Wang, A., Shi, Y., Li, X. (2011). Performance and model of a full-scale up-flow anaerobic sludge blanket (UASB) to treat the pharmaceutical wastewater containing 6-APA and amoxicillin. Journal of Hazardous Materials, 185(2-3): 905-913. https://doi.org/10.1016/j.jhazmat.2010.09.106

[9] Stazi, V., Tomei, M.C. (2018). Enhancing anaerobic treatment of domestic wastewater: State of the art, innovative technologies and future perspectives. Science of the Total Environment, 635: 78-91. https://doi.org/10.1016/j.scitotenv.2018.04.071

[10] Toloti, A.A., Mehrdadi, N. (2011). Wastewater treatment from antibiotics plant. International Journal of Environmental Research, 5(1): 241-246.

[11] Chong, S., Sen, T.K., Kayaalp, A., Ang, H.M. (2012). The performance enhancements of upflow anaerobic sludge blanket (UASB) reactors for domestic sludge 
treatment-a state-of-the-art review. Water Research, 46(11): 3434-3470 https://doi.org/10.1016/j.watres.2012.03.066

[12] Rajakumar, R., Meenambal, T., Banu, J.R., Yeom, I.T. (2011). Treatment of poultry slaughterhouse wastewater in upflow anaerobic filter under low upflow velocity. International Journal of Environmental Science \& Technology, $8(1)$ : 149-158 https://doi.org/10.1007/BF03326204

[13] Kerroum, D., Mossaab, B.L., HASSEN, M.A. (2010). Use of ADM1 model to simulate the anaerobic digestion process used for sludge waste treatment in thermophilic conditions. Turkish Journal of Engineering and Environmental Sciences, 34(2): 121-130.

[14] Milquez-Sanabria, H., Blanco-Cocom, L., AlzateGaviria, L. (2016). A fast linear predictive adaptive model of packed bed coupled with UASB reactor treating onion waste to produce biofuel. Microbial Cell Factories, 15(1): 167.

[15] Biswas, J., Chowdhury, R., Bhattacharya, P. (2007). Mathematical modeling for the prediction of biogas generation characteristics of an anaerobic digester based on food/vegetable residues. Biomass and Bioenergy, 31(1): 80-86. https://doi.org/10.1016/j.biombioe.2006.06.013

[16] Rajaee, T., Ebrahimi, H., Nourani, V. (2019). A review of the artificial intelligence methods in groundwater level modeling. Journal of Hydrology, 572: 336-351.

[17] Zhao, L., Dai, T., Qiao, Z., Sun, P., Hao, J., Yang, Y. (2020). Application of artificial intelligence to wastewater treatment: A bibliometric analysis and systematic review of technology, economy, management, and wastewater reuse. Process Safety and Environmental Protection, 133: 169-182. https://doi.org/10.1016/j.psep.2019.11.014

[18] Long, S., Zhao, L., Liu, H., Li, J., Zhou, X., Liu, Y., Yang, Y. (2019). A Monte Carlo-based integrated model to optimize the cost and pollution reduction in wastewater treatment processes in a typical comprehensive industrial park in China. Science of the Total Environment, 647: 110. https://doi.org/10.1016/j.scitotenv.2018.07.358

[19] Loos, R., Carvalho, R., António, D.C., Comero, S., Locoro, G., Tavazzi, S., Jarosova, B. (2013). EU-wide monitoring survey on emerging polar organic contaminants in wastewater treatment plant effluents. Water Research, 47(17): 6475-6487. https://doi.org/10.1016/j.watres.2013.08.024

[20] Huang, M.Z., Wan, J.Q., Ma, Y.W., Wang, Y., Li, W.J., Sun, X.F. (2009). Control rules of aeration in a submerged biofilm wastewater treatment process using fuzzy neural networks. Expert Systems with Applications, 36(7): 10428-10437. https://doi.org/10.1016/j.eswa.2009.01.035

[21] Huang, M., Ma, Y., Wan, J., Chen, X. (2015). A sensorsoftware based on a genetic algorithm-based neural fuzzy system for modeling and simulating a wastewater treatment process. Applied Soft Computing, 27: 1-10. https://doi.org/10.1016/j.asoc.2014.10.034

[22] Mamais, D., Noutsopoulos, C., Dimopoulou, A., Stasinakis, A., Lekkas, T.D. (2015). Wastewater treatment process impact on energy savings and greenhouse gas emissions. Water Science and Technology, 71(2): 303-308.

[23] Wan, J., Huang, M., Ma, Y., Guo, W., Wang, Y., Zhang,
H., Sun, X. (2011). Prediction of effluent quality of a paper mill wastewater treatment using an adaptive network-based fuzzy inference system. Applied Soft Computing, 11(3): 3238-3246. https://doi.org/10.1016/j.asoc.2010.12.026

[24] Sinha, S., Bose, P., Jawed, M., John, S., Tare, V. (2002). Application of neural network for simulation of upflow anaerobic sludge blanket (UASB) reactor performance. Biotechnology and Bioengineering, 77(7): 806-814. https://doi.org/10.1002/bit.10168

[25] Tan, H.M., Gouwanda, D., Poh, P.E. (2018). Adaptive neural-fuzzy inference system vs. anaerobic digestion model No. 1 for performance prediction of thermophilic anaerobic digestion of palm oil mill effluent. Process Safety and Environmental Protection, 117: 92-99. https://doi.org/10.1016/j.psep.2018.04.013

[26] Tu, J.V. (1996). Advantages and disadvantages of using artificial neural networks versus logistic regression for predicting medical outcomes. Journal of Clinical Epidemiology, 49(11): 1225-1231.

[27] Ekel, P., Kokshenev, I., Palhares, R., Parreiras, R., Neto, F.S. (2011). Multicriteria analysis based on constructing payoff matrices and applying methods of decision making in fuzzy environment. Optimization and Engineering, 12(1-2): 5-29.

[28] Zadeh, L.A. (2008). Is there a need for fuzzy logic? Information Sciences, 178(13): 2751-2779. https://doi.org/10.1016/j.ins.2008.02.012

[29] Saltelli, A., Annoni, P., Azzini, I., Campolongo, F., Ratto, M., Tarantola, S. (2010). Variance based sensitivity analysis of model output. Design and estimator for the total sensitivity index. Computer Physics Communications, $181(2)$ : 259-270. https://doi.org/10.1016/j.cpc.2009.09.018

[30] Tian, W. (2013). A review of sensitivity analysis methods in building energy analysis. Renewable and Sustainable Energy Reviews, 20: 411-419. https://doi.org/10.1016/j.rser.2012.12.014

[31] Kumar, A., Bhatia, N. (2011). A new method for solving fuzzy sensitivity analysis problems. International Journal of Applied Science and Engineering, 9(2): 49-64.

[32] Singh, J.P., Thakur, N.I. (2015). Novel Method for Sensitivity Analysis of Fully Fuzzy Linear Programming Problem by Tabular Method.

[33] Souleymane, K., Tang, Z. (2017). A novel method of sensitivity analysis testing by applying the DRASTIC and fuzzy optimization methods to assess groundwater vulnerability to pollution: the case of the Senegal River basin in Mali. Natural Hazards and Earth System Sciences, 17(8): 1375

[34] Rizvi, H., Ahmad, N., Abbas, F., Bukhari, I.H., Yasar, A., Ali, S., Riaz, M. (2015). Start-up of UASB reactors treating municipal wastewater and effect of temperature/sludge age and hydraulic retention time (HRT) on its performance. Arabian Journal of Chemistry, $8(6)$ : 780-786. https://doi.org/10.1016/j.arabjc.2013.12.016

[35] Patel, S.J., Jamaluddin, S. (2018). Treatment of distillery waste water: A review. Int. J. Theor. Appl. Sci, 10(1): 117-139.

[36] León-Becerril, E., García-Camacho, J.E., Del RealOlvera, J., López-López, A. (2016). Performance of an upflow anaerobic filter in the treatment of cold meat industry wastewater. Process Safety and Environmental 
Protection,

102:

$385-391$

https://doi.org/10.1016/j.psep.2016.04.016

[37] Zadeh, L.A. (1965). Fuzzy set. Inform Contr; 8: 338-353.

[38] Mamdani, E.H. (1974). Application of fuzzy algorithms for control of simple dynamic plant. In Proceedings of the Institution of Electrical Engineers, 121(12): 15851588.

[39] Tanyildizi, H. (2009). Fuzzy logic model for the prediction of bond strength of high-strength lightweight concrete. Advances in Engineering Software, 40(3): 161169. https://doi.org/10.1016/j.advengsoft.2007.05.013

[40] Tyagi, K., Sharma, A. (2012). A rule-based approach for estimating the reliability of component-based systems. Advances in Engineering Software, 54: 24-29. https://doi.org/10.1016/j.advengsoft.2012.08.001

[41] Varne, A.L., Macwan, J.E.M. (2012). Fuzzy rule based approach for modeling biogas production rate in a real scale UASB reactor treating distillery wastewater. Journal of Environmental Research and Development, 6(3A): 788-801.

[42] Ojha, V., Abraham, A., Snášel, V. (2019). Heuristic design of fuzzy inference systems: A review of three decades of research. Engineering Applications of Artificial Intelligence, 85: 845-864. https://doi.org/10.1016/j.engappai.2019.08.010

[43] Turkdogan-Aydınol, F.I., Yetilmezsoy, K. (2010). A fuzzy-logic-based model to predict biogas and methane production rates in a pilot-scale mesophilic UASB reactor treating molasses wastewater. Journal of Hazardous Materials, 182(1-3): 460-471. https://doi.org/10.1016/j.jhazmat.2010.06.054

[44] Khatua, A., Jana, S., Kar, T.K. (2020). A fuzzy rulebased model to assess the effects of global warming, pollution and harvesting on the production of Hilsa fishes. Ecological Informatics, 57: 101070. https://doi.org/10.1016/j.ecoinf.2020.101070

[45] Chun-Te Lin, J., Liu, Y.S., Wang, W.K. (2020). A fullscale study of high-rate anaerobic bioreactors for whiskey distillery wastewater treatment with size fractionation and metagenomic analysis of granular sludge. Bioresource Technology, 306: 123032. https://doi.org/10.1016/j.biortech.2020.123032

[46] Xie, S., Hai, F.I., Zhan, X., Guo, W., Ngo, H.H., Price, W.E., Nghiem, L.D. (2016). Anaerobic co-digestion: A critical review of mathematical modelling for performance optimization. Bioresource Technology, 222: 498-512. https://doi.org/10.1016/j.biortech.2016.10.015

[47] Borisov, M., Dimitrova, N., Simeonov, I. (2016). Mathematical modelling of anaerobic digestion with hydrogen and methane production. IFAC-PapersOnLine, 49(26):

231-238. https://doi.org/10.1016/j.ifacol.2016.12.131

[48] Kacimi, M.A., Guenounou, O., Brikh, L., Yahiaoui, F., Hadid, N. (2020). New mixed-coding PSO algorithm for a self-adaptive and automatic learning of Mamdani fuzzy rules. Engineering Applications of Artificial Intelligence, 89:

103417

https://doi.org/10.1016/j.engappai.2019.103417

[49] Ahmadi, M.H.E., Royaee, S.J., Tayyebi, S., Boozarjomehry, R.B. (2020). A new insight into implementing Mamdani fuzzy inference system for dynamic process modeling: Application on flash separator fuzzy dynamic modeling. Engineering Applications of Artificial Intelligence, 90: 103485.
[50] Mazhar, S., Ditta, A., Bulgariu, L., Ahmad, I., Ahmed, M., Nadiri, A.A. (2019). Sequential treatment of paper and pulp industrial wastewater: Prediction of water quality parameters by Mamdani Fuzzy Logic model and phytotoxicity assessment. Chemosphere, 227: 256-268. https://doi.org/10.1016/j.chemosphere.2019.04.022

[51] Acaroglu, O., Ozdemir, L., Asbury, B. (2008). A fuzzy logic model to predict specific energy requirement for TBM performance prediction. Tunnelling and Underground Space Technology, 23(5): 600-608. https://doi.org/10.1016/j.tust.2007.11.003

[52] Dash, R., Dash, P.K. (2017). MDHS-LPNN: a Hybrid forex predictor model using a legendre polynomial neural network with a modified differential Harmony search technique. In Handbook of Neural Computation, 459-486. https://doi.org/10.1016/B978-0-12-8113189.00025-9

[53] Alavi, A.H., Gandomi, A.H., Mollahasani, A., Bazaz, J. B., Talatahari, S. (2013). Linear and tree-based genetic programming for solving geotechnical engineering problems. Metaheuristics in Water, Geotechnical and Transport Engineering, 289-310.

[54] Adetiloye, T., Awasthi, A. (2017). Predicting short-term congested traffic flow on urban motorway networks. In Handbook of Neural Computation, 145-165. http://dx.doi.org/10.1016/B978-0-12-811318-9.00008-9

[55] Pal, R. (2017). Validation methodologies. Predictive Modeling of Drug Sensitivity, 83-107. http://dx.doi.org/10.1016/B978-0-12-805274-7.00004-X

[56] Massada, A.B., Carmel, Y. (2008). Incorporating output variance in local sensitivity analysis for stochastic models. Ecological Modelling, 213(3-4): 463-467. https://doi.org/10.1016/j.ecolmodel.2008.01.021

[57] Radaideh, M.I., Radaideh, M.I. (2020). Efficient analysis of parametric sensitivity and uncertainty of fuel cell models with application to SOFC. International Journal of Energy Research, 44(4): 2517-2534. http://dx.doi.org/10.1002/er.4837

[58] Calderón, C.J., Ancheyta, J. (2019). Modeling, simulation, and parametric sensitivity analysis of a commercial slurry-phase reactor for heavy oil hydrocracking. Fuel, 244: 258-268. https://doi.org/10.1016/j.fuel.2019.01.138

[59] Olvera-García, M.Á., Carbajal-Hernández, J.J., SánchezFernández, L.P., Hernández-Bautista, I. (2016). Air quality assessment using a weighted Fuzzy Inference System. Ecological Informatics, 33: 57-74. https://doi.org/10.1016/j.ecoinf.2016.04.005

[60] Ndobeni, A., Oyekola, O., Welz, P.J. (2019). Organic removal rates and biogas production of an upflow anaerobic sludge blanket reactor treating sugarcane molasses. South African Journal of Chemical Engineering, 28 : https://doi.org/10.1016/j.sajce.2019.01.002

[61] Cakmakci, M. (2007). Adaptive neuro-fuzzy modelling of anaerobic digestion of primary sedimentation sludge. Bioprocess and Biosystems Engineering, 30(5): 349-357. https://doi.org/10.1007/s00449-007-0131-2

[62] Ramaraj, R., Unpaprom, Y. (2016). Effect of temperature on the performance of biogas production from Duckweed. Chemistry Research Journal, 1(1): 58-66.

[63] Lohani, S.P., Wang, S., Bergland, W.H., Khanal, S.N., Bakke, R. (2018). Modeling temperature effects in anaerobic digestion of domestic wastewater. Water- 
Energy $\quad$ Nexus, $1(1)$ : 56-60. http://dx.doi.org/10.1016/j.wen.2018.07.001

[64] Satyawali, Y., Balakrishnan, M. (2008). Wastewater treatment in molasses-based alcohol distilleries for COD and color removal: A review. Journal of Environmental Management, 86(3): 481-497. https://doi.org/10.1016/j.jenvman.2006.12.024

[65] Nippatla, N., Philip, L. (2019). Electrocoagulationfloatation assisted pulsed power plasma technology for the complete mineralization of potentially toxic dyes and real textile wastewater. Process Safety and Environmental Protection, 125: 143-156. https://doi.org/10.1016/j.psep.2019.03.012

[66] Charalambous, P., Shin, J., Shin, S.G., Vyrides, I. (2020). Anaerobic digestion of industrial dairy wastewater and cheese whey: Performance of internal circulation bioreactor and laboratory batch test at $\mathrm{pH}$ 5-6. Renewable $\quad$ Energy, 147: 1-10. https://doi.org/10.1016/j.renene.2019.08.091

[67] Syaichurrozi, I., Suhirman, S., Hidayat, T. (2018). Effect of initial $\mathrm{pH}$ on anaerobic co-digestion of Salvinia molesta and rice straw for biogas production and kinetics. Biocatalysis and Agricultural Biotechnology, 16: 594603.

[68] Kumar, V., Kumar, P., Kumar, P., Singh, J. (2020). Anaerobic digestion of Azolla pinnata biomass grown in integrated industrial effluent for enhanced biogas production and COD reduction: Optimization and kinetics studies. Environmental Technology \& Innovation, $17:$ 100627. https://doi.org/10.1016/j.eti.2020.100627

[69] Satyawali, Y., Balakrishnan, M. (2008). Wastewater treatment in molasses-based alcohol distilleries for COD and color removal: A review. Journal of Environmental Management, 86(3): 481-497. https://doi.org/10.1016/j.jenvman.2006.12.024

[70] Yetilmezsoy, K., Sakar, S. (2008). Development of empirical models for performance evaluation of UASB reactors treating poultry manure wastewater under different operational conditions. Journal of Hazardous Materials, 153(1-2): 532-543. https://doi.org/10.1016/j.jhazmat.2007.08.087

[71] Torkian, A., Eqbali, A., Hashemian, S.J. (2003). The effect of organic loading rate on the performance of UASB reactor treating slaughterhouse effluent. Resources, Conservation and Recycling, 40(1): 1-11. https://doi.org/10.1016/S0921-3449(03)00021-1

[72] Sakar, S., Yetilmezsoy, K., Kocak, E. (2009). Anaerobic digestion technology in poultry and livestock waste treatment - a literature review. Waste Management \& Research, 27(1): 3-18. 